\title{
Bibliographic synthesis on biology and ecology of Hoplobatrachus occipitalis (Günther, 1858)
}

\author{
Théophile GODOME ${ }^{1,2^{*}}$, Ephrem TOSSAVI ${ }^{1}$, Nahoua Issa OUATTARA $^{2}$ and \\ Emile Didier FIOGBE ${ }^{1,2}$
}

\author{
${ }^{1}$ Laboratory of Research on Wetlands, Department of Zoology, Faculty of Sciences and Techniques, University \\ of Abomey-Calavi, BP: 526 Cotonou, Benin. \\ ${ }^{2}$ Laboratory of Hydrobiology, UFR Biosciences, University Félix Houphouet-Boigny, 22 BP: 582 Abidjan 22, \\ Côte d'Ivoire. \\ *Corresponding author; E-mail: theogod87@gmail.com; Tel: (+229) 95646517
}

\section{ACKNOWLEGMENTS}

The authors thank World Bank through African Center of Excellence on Climate, Biodiversity and Sustainable Agriculture (CEA-CCBAD) for financial support.

\begin{abstract}
Hoplobatrachus occipitalis is a frog belonging to Dicroglossidae family, the most spread in West Africa. This study aimed at performing to bibliographic synthesis on biology and ecology of this species in order to assess its potential in aquaculture. It lives along banks, rocky reservoirs and earthen ponds and prefers savannah areas. It feeds on coleopterans, caterpillars, spiders, vegetal fragments, fishes, crabs, ants, grasshoppers, locusts, dragonflies, frogs, mollusks, lizards, mice, butterflies, wasps and diptera larvae. The growth of $H$. occipitalis depend on the temperature and $\mathrm{pH}$ of the medium. A pH range 6.2 and 7 and temperature equal or upper, than $28{ }^{\circ} \mathrm{C}$ are suitable for its growth. $H$. occipitalis is an oviparous species. Its first sexual maturity height is $124.5 \mathrm{~mm}$ for females and $95 \mathrm{~mm}$ for males and it often reproduces during rainy season. The rapid growth, resistance and high nutritional quality of this species are some of its important potentialities for aquaculture. Natural reserves of $H$. occipitalis are overexploited and therefore no more able to satisfy the populations demand. A successful breeding of this species can help not only to preserve and strengthen the natural reserves but to produce regularly bulbous crowfoot for human consumption.
\end{abstract}

(C) 2018 International Formulae Group. All rights reserved.

Keywords: Hoplobatrachus occipitalis, biology, ecology, aquaculture potentialities.

\section{INTRODUCTION}

Worldwide fresh water aquaculture production reaches 47.1 million tons during 2015 owing to the rapid development of rearing technique of certain species such as Nile Tilapia (Oreochromis niloticus), Clarias gariepinus, some amphibians (frog, toad, tritons and salamanders) and others (FAO, 2016).

In Africa, continental aquaculture produces 1.7 million tons during 2015 and is made of fishes, mollusks, crustacea and other aquatic animals including frog (FAO, 2016).

Frog is an amphibian that may be naturally found in tropical and subtropical 
climate regions. Like every amphibian, it is a poikilotherm animal. Likewise, its growth is directly tied to the temperature. Another characteristic is the double respiratory system, either pulmonary or cutaneous (Morin, 2008).

Ecologically, these animals play an important role in food web and are indispensable to wetlands balance maintaining (Channing, 2001). Frogs are excellent bioindicators of aquatic environment (Schiøtz, 1999; Rödel, 2000; Channing, 2001; Guerry and Hunter, 2002). Indeed, they consume harmful insects reducing therefore their population. By doing so, they enhance agricultural production and contribute to the fight against malaria vectors (Channing, 2001).

Economically, some edible frog species like Hoplobatrachus occipitalis constitute a source of animal genuine proteins and income to men (Neveu, 2004; Nzigidahera, 2006).

Several studies inform on the diet (Alfredo, 1996; Mady-Goma, 2012), the biology (Wells, 1977; Barbault, 1984; Heyer et al., 1994; Rödel, 2000; Morin, 2008; Tohé, 2009), the ecology (Rödel, 2000 ; Wildlife et al., 2007; Tohé, 2009), the parasitology (Akani et al., 2011; Aisien et al., 2014) and the sensitivity to heavy metals (James and Little, 2003 ; Ezemonye and Enuneku 2005; Sobha et al., 2007; Ezemonye and Enuneku, 2011; Idowu et al., 2014; Omonona et al., 2016) of $H$. occipitalis, but studies regarding frogs rearing especially $H$. occipitalis from larval stage to adult are scarce in West Africa. Besides, data on the feeding habit of this frog species are very important for the qualification of its growth performance and production cost reduction. $H$. occipitalis rearing in controlled medium can help promoting these species. In order to preserve and strengthen the natural stock. The rearing achievement of this frog species requires knowledge on its biology, ecology and aquaculture potential. This article summarizes some studies on $H$. occipitalis.

\section{MORPHOLOGY DESCRIPTION OF $\boldsymbol{H}$. OCCIPITALIS}

H. occipitalis is a large and flat ranidae with globular eyes which diameter ranges, from 0.7 to $0.9 \mathrm{~mm}$; several dorsal warts arranged longitudinally and a minuscule internal metatarsal tubercle. It has a complete strap between fingers and toes; a very verrucose skin though eyes and nostrils are dorsally positioned. The skin is very slippery due to numerous glands. Mussel-anal length of adult males varies from 52 to $104 \mathrm{~mm}$ and that of the biggest females measured in the national zoo area of Comoé was $65 \mathrm{~mm}$. According to Loveridge (1955), mature female of $H$. occipitalis can weight $235 \mathrm{~g}$ with a mussel-anal length about $127 \mathrm{~mm}$. However, Perret (1966) reported mussel-anal length varies from 52 to $110 \mathrm{~mm}$ in males and 110 to $135 \mathrm{~mm}$ in females. Males weight varies from 24 to $84 \mathrm{~g}$ and while females weigh from 20 to $132 \mathrm{~g}$ (Rödel, 2000). H. occipitalis specimens individuals have a large mouth. The side of inferior jaw carries three teeth. They pupil are oval and vertical. The eardrum is distinct and bordered by a bent supratympanic fold. Males have pairs of lateral vocal sack and large thenar tubercle; the skin surrounding vocal sacks in the throat is strongly folded. Posterior members are relatively short and muscled than anterior members. Stems are generally longer than thighs. There are many small tubercles on the posterior part of thighs (Rödel, 2000).

The body color of $H$. occipitalis is green-yellowish, olive or brown-dull; its back presents greenish or blackish spots which sometimes form lines. Black spots are also present on the superior lip; most of individuals have their throat and inferior lip white colored with rarely some black spots. The external parts of thighs are marbled. The belly is white with sometimes some black spots (Rödel, 2000); vocal sacks are grey, bluish (Burton, 1972) or cream colored (Loveridge, 1955).

\section{SYSTEMATICAL POSITION OF HOPLOBATRACHUS OCCIPITALIS}

The species name has progressed as a function of time. Indeed, Rana occipitalis (Scortecci, 1936), Rana tigrina occipitalis (Dekeyser and Villiers, 1956), Hoplobatrachus occipitalis (Dubois, 1992) are synonym to Hoplobatrachus occipitalis (Günther, 1859). According to Frost et al. (2006), Hoplobatrachus occipitalis belongs to 
Regnum of Animalia; Phyllum of Chordata; Sub-phyllum of Vertebrata; Class of Amphibia; Sub-class of Lissamphibia; Superorder of Salienta; Order of Anura; Familia of Dicroglossidae; Sub-familia of Dicroglossinae and Genus Hoplobatrachus.

\section{GEOGRAPHICAL DISTRIBUTION}

Hoplobatrachus occipitalis distribution is mainly disjunctive including the Northern Africa (Morocco, Algeria and Libya) stock and a great part from subSaharan Africa. These populations can still be considered isolate with sub-populations in the South-West of Libyan Jamahiriya Arab, South-East of occidental Sahara and close to Mauritania, Mountains area of Niger and the Northern Mali. In sub-Saharan Africa, it is found on the Atlantic coast by the East, in Ethiopia, Chad, Sudan and Southern Angola and Mozambique. Other sub-Saharan African countries such as Northern Zambia, Western Congo, Senegal, Gambia, Bissau Guinea, Liberia, Sierra Leone, Guinea, Mali, Burkina Faso, Ivory Coast, Ghana, Togo, Benin, Niger, Nigeria, Cameroon, Equatorial Guinea (including Fernando Pó isle), Congo, Democratic Republic of Congo, Republic of Centrafrica, Uganda, Kenya, Tanzania, Rwanda and Burundi (Rödel, 2000). Research carried out by Frost (1985) confirm the existence of $H$. occipitalis in the area of Senegal to Ethiopia, from Northern to Southern Zambia, Angola and Southern Congo. According to Alfredo (1996), $H$. occipitalis is an Ethiopian species recorded in the North-West Africa, South-West Libya, Adrar Iforas (Mali), Adrar (Mauritania) and the rocky areas of Niger.

\section{ECOLOGY}

H. occipitalis inhabits along river banks, rocky reservoirs and earthen ponds with a preference to savannah environments. This species may be found in some woody area (Poynton and Broadley, 1985) and in an eco-region with both savannah and forest: that is the case of Miombo forest of central Zambia (Gruschwitz et al., 1991). It also dwells into rocky reservoirs of rivers surrounding by primary forest where high water temperature (until $40{ }^{\circ} \mathrm{C}$ ) is recorded
(Rödel, 2000; Wildlife et al., 2007). Its natural habitats are thus sub-tropical forests, dry savannah, wet savannah, tropical or subtropical prairie of dry plains, tropical or subtropical prairie of periodically flooded plain, rivers and intermittent rivers, fresh water lakes and intermittent fresh water lakes, fresh water swamp and intermittent fresh water swamp, fresh water sources, tillable grounds, pastures, rural gardens and ponds (Rödel, 2000).

According to Alfredo (1996), in Northern Africa, H. occipitalis dwells in oasis, in mountain regions where it lives in wells and cisterns. It is active the day and inactive at night and during the winter.

Besides, the life cycle of frogs includes two distinct stages: aquatic stage and terrestrial stage. The last one requires consumption of high proteins value feed for their growth (Olvera-Novoa et al., 2007).

Nevertheless, they have a rapid growth in hot climates and low in temperate climates due to their poïkilotherm characteristic. Therefore, they hibernate and their activity is limited to the mid of year in temperate climate (Morin, 2008). Especially, temperature is important for the growth of $H$. occipitalis since values upper than $28{ }^{\circ} \mathrm{C}$ enable its normal growth but at values lower than $25^{\circ} \mathrm{C}$, the growth is slowed down. Furthermore, a pH ranged between 6.2 and 7 does not influence the growth of $H$. occipitalis (Nzigidahera, 2006). It is important to notice that a period of two years is necessary for them to reach sexual maturity and more for commercial height (Morin, 2008).

\section{FOOD HABIT}

Generally, frogs are recognized like electrical diet animals (Perret, 1966). They are live prey predators. $H$. occipitalis essentially feeds on coleopterans, caterpillars, spiders, vegetal fragment, fishes, crabs, ants, grasshoppers, locusts, dragonflies, frogs, mollusks, lizards, mice, butterflies, wasps (Mady-Goma, 2012). According to Alfredo (1996), it feeds on coleopterans, orthopterans, toads (de Xeros Bufo) and their tadpoles and individuals from their own species. Rödel (2000) reported that $H$. occipitalis larvae are carnivorous though preys are larvae from other frog species, mosquito larvae and other 
aquatic species larvae. An observation of their stomach content showed Coleopterans, Diptera, Lepidoptera, Hymenoptera, Orthopterans, mollusks, soft substances and vegetal fragments (Nzigidahera, 2006). Lescure (1971) showed that $H$. occipitalis diet includes essentially Coleopterans, spiders and Orthopterans. These predators select their prey according to its speed, movement and size. The important proportion of Coleopterans in the frog diet indicates its ability to live nearby rivers (Inger and Marx, 1961; Rödel, 1995). Observations made by Loveridge (1942) showed $H$. occipitalis feeds on other frog species. Also, Noble (1924) reported this frog feeds on its fellows. According to Kühn et al. (1987), all ranidae, insects and fishes are considered as prey of $H$. occipitalis which lives in water during the day. It leaves the water for hunting at night but in full moon period it stays in water. In Northern Africa, H. occipitalis is active in the day and at night but inactive during the winter (Alfredo, 1996). Spieler and Linsenmair (1998) confirmed this species is active at night and stay hidden from the sun rise to sunset.

Moreover, food conditions of frog are not well defined. Carnivorous fish rations are used in frog rearing farm (Casali et al., 2005).

\section{REPRODUCTION}

Reproduction is an important factor to the success of intensive production of animal. Moreover, frogs reproduce only during hot temperature period. In temperate climates, frogs reproduce only during the summer (Morin, 2008).

However, the reproduction of $H$. occipitalis occurs in the rainy season under sub-tropical climate (Rödel, 2000). Males are small and possess vocal sacks which are powerful resonator (Perret, 1966). The first maturity height is $124.5 \mathrm{~mm}$ for females and $95 \mathrm{~mm}$ for males (Tohé et al., 2016). The least height of first maturity for females is $122 \mathrm{~mm}$ and $68 \mathrm{~mm}$ for males. All individuals reach sexual maturity at $130 \mathrm{~mm}$ for females and $120 \mathrm{~mm}$ for males (Tohé et al., 2016). Their croaking is especially tied in reproduction (Wells, 1977; Heyer et al., 1994). Females of $H$. occipitalis show an annual variation in their reproduction capacity even in constant environmental conditions (photoperiod, temperature, precipitations, humidity) (Kühn et al., 1987). This is especially favoured in ponds near rivers filled up by the firs rain (van den Elzen and Kreulen, 1979). Thus males floating at water surface attract females by their croaking. Spawn often happens in the water and eggs quantity may range between 800 and 1500 (Barbault, 1984; Rödel, 2000).

Eggs are laid individually or in small group forming sticking frost on rocks or stones at the water bottom. The sticking frosts are covered by algae and detritus making eggs are less visible. Eggs diameter averages $5 \mathrm{~mm}$ at pharyngula stage and $3.2 \mathrm{~mm}$ at neurula stage (Rödel, 2000). According to Tohé et al. (2016), mature eggs size is $2.74 \mathrm{~mm}$.

A study led by Zug (1987), show eggs measured $1.6 \mathrm{~mm}$ to $1.8 \mathrm{~mm}$ and possess black and white poles. Parker (1936) described clutch as a huge floating egg mass. However, these authors have made confusion between Hoplobatrachus occipitalis eggs and those from other species (probably Phrynomantis microps).

\section{PARASITE FAUNA OF HOPLOBATRACHUS OCCIPITALIS}

Parasites are the most recorded pathogens in aquaculture. Parasitological studies are so very important for the development of fish breeding potential in fresh water habitats. Some studies showed Hoplobatrachus occipitalis may be infested in different organs by several parasites (Table 1).

\section{HEMATOLOGY AND SENSITIVITY TO HEAVY METALS}

Cadmium is a heavy metal without any biological function. It is very toxic to both aquatic and terrestrial organisms. It was introduced in aquatic environment mainly by human activities including mine exploitation, fertilizers using and industrial discharges (Volgiatzis and Loumbourdis, 1997; James and Little, 2003; Ezemonye and Enuneku, 2005). Adult frogs can absorb cadmium by skin or by oral way by consuming water and by respiration (Ezemonye and Enuneku, 2011). Then, it can pass through many tissues particularly liver, kidneys, gonads, placenta, 
brain, bones and blood (Sobha et al., 2007; Omonona et al., 2016).

Furthermore $H$. occipitalis accumulates highly zinc, following successively by iron, copper, Nickel and lead (Idowu et al., 2014).

\section{PROSPECTIVE FOR AQUACULTURE}

Frogs constitute an important animal proteins source in Africa (Onadeko et al., 2011). Populations of Nigeria, Côte d'Ivoire, Benin and Burkina Faso include increasingly frog meat in their menu: either grilled or boiled. Fishermen obtained 20 dollars for a thousand of dried frog. Most of them were adapted to this activity because it is more profitable than fish (DDC, 2010). The extent of this activity constitutes a threat to ecosystems. H. occipitalis is more appreciated by consumers but its tadpoles are useful because for example, they consume mosquito larvae (DDC, 2010). Biologist required frogs rearing farm in order to preserve wild populations (DDC, 2010).

According to Nzigidahera (2006), exploitation of edible frogs constitutes a source of income. For instance, peasants sell edible frogs Hoplobatrachus and Ptychadena to big hotels and restaurants in Bujumbura (Nzigidahera, 2006). Therefore, H. occipitalis is the most sold because it is easy to harvest and has a big thigh with an important economical value.

A survey made by "Fondation Droit Animal", Sciences and Ethic (LFDA) during the first months of years 2008 and 2009 in three countries (Nigeria, Benin and Burkina Faso) by questioning villagers, commercials, hunters, dealers and customer-consumers showed that among the 25 species considered, H. occipitalis is the most consumed in both Burkina Faso and Nigeria following by Pyxicephalus edulis, Ptychadena bibroni, Ptychadena oxyrynchus and Ptychadena trinodis (LFDA, 2011). Frogs sale concerns mainly human consumption. However, certain species are used in traditional medicine, especially toads or frogs resembling to toads (LFDA, 2011).

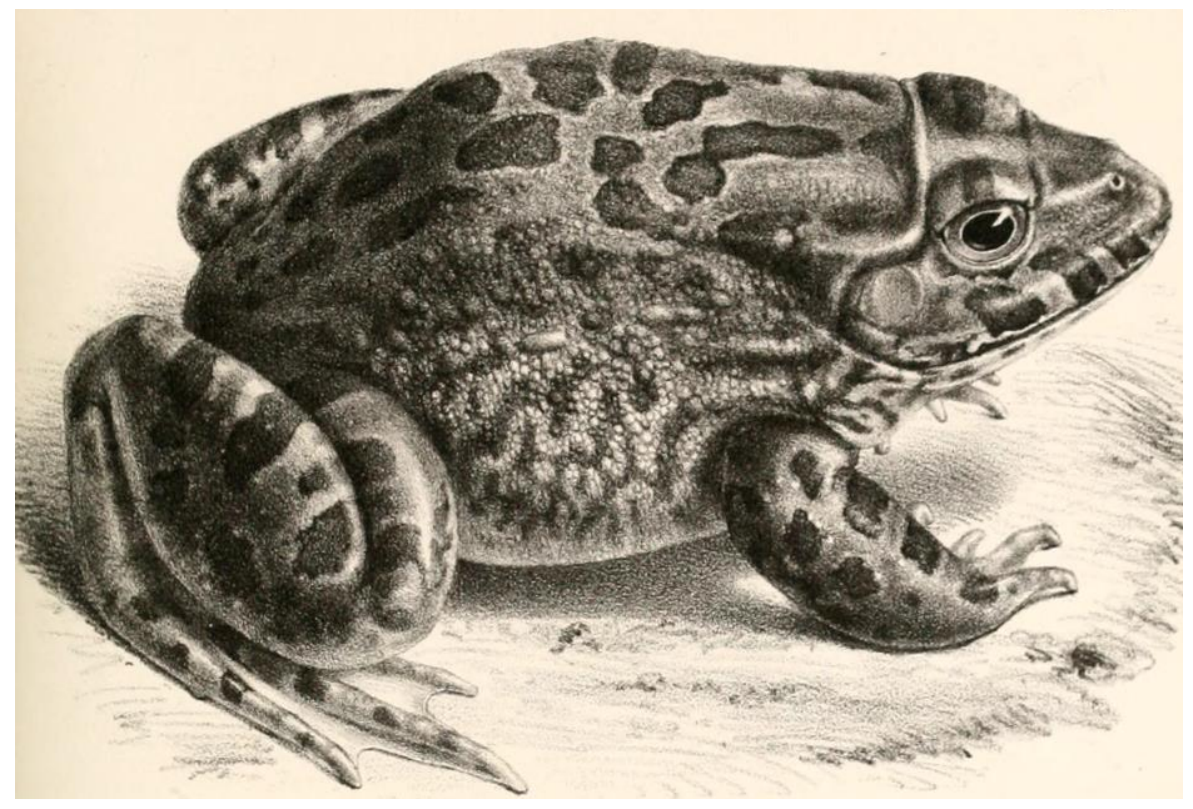

Figure 1: Specimen of Hoplobatrachus occipitalis (Günther, 1858). 




- Residence zone of the species

Figure 2: Distribution of Hoplobatraclius occipitalis in Africa (Cartographical Data@2017 Google. INEGI).

Table 1: Parasites of Hoplobatrachus occipitalis and infested organs.

\begin{tabular}{lll}
\hline Parasites (Species) & Phylum & Organs \\
\hline Microfilariae Folleyellides sp (Aisien et al., 2014) & Nematoda & Blood \\
\hline Aplectana acuminata (Akani et al., 2011) & Nematoda & Bowel \\
& & \\
\hline Oxyuris sp. (Akani et al., 2011) & Nematoda & Bowel and Colon \\
\hline Eurytrema sp. (Akani et al., 2011) & Nematoda & Stomach, Bowel and \\
& & colon \\
\hline Diphyllobothrium sp. (Akani et al., 2011) & & Bowel \\
\hline Eimeria terraepokotorum (Miloslav et al., 2006) & coccida & Bowel \\
\hline
\end{tabular}




\section{CONCLUSION}

In summary, we can say that $H$. occipitalis is a very robust species that deserves to be reared because it is an important source of animal genuine protein for humans. Also, in the major hotels of most of African countries, H. occipitalis is the bestselling species because it is easy to harvest and has a fairly large thigh with a significant economic value.

\section{COMPETING INTERESTS}

The authors declare that there is no competing interests.

\section{AUTHORS' CONTRIBUTIONS}

All authors have made adequate effort on all parts of the work necessary for the development of this manuscript according to his expertise. All authors read and approved the final manuscript.

\section{REFERENCES}

Aisien MSO, Aigbirior PO, Ovwah E, EdoTaiwo O. 2014. Blood parasites of some Anurans from southern Nigeria. Tropical Biomedicine, 32(4): 598-607. https://www.researchgate.net/.../2906500 20_Blood_parasites_of_s...

Akani1 GC, Luiselli L, Amuzie CC, Wokem GN. 2011. Helminth community structure and diet of three Afrotropical anuran species: a test of the interactiveversus-isolationist parasite communities hypothesis. Web Ecol., 11: 11-19. https://doi.org/10.5194/we-11-11-2011

Alfredo S. 1996. Amphibians of Northwest Africa. Smithsonian Herpetological Information. Service. No. 109. 45p. citeseerx.ist.psu.edu/viewdoc/download? doi=10.1.1.455...

Barbault R. 1984. Stratégie de reproduction et démographie de quelques amphibiens anoures tropicaux. Oikos, 43: 77-87. Doi: $10.2307 / 3544248$

Burton RV. 1972. Croos-sex Identity in Barbados. Developmental Psycology 6 : 365-374. Doi: 10.1037/h0032580

Casali AP, Moura OM, Lima SL, Silva JHV.
2005. Avaliação de rações comerciais nas fases de crescimento e terminação da recria de rã-touro. Boletim do Instituto de Pesca, 31(1): $37-46$ ftp://ftp.sp.gov.br/ftppesca/Casali31_1.p df

Channing A. 2001. Amphibian of Central and Southern Africa. Cornell University Press, Ithaca, New York, 496pp. www.cornellpress.cornell.edu/book/?GC $\mathrm{OI}=80140100275230$

DDC (Direction du Développement et de la Coopération), 2010. Un seul monde; $\mathrm{N}^{\circ} 3 /$ le magazine de la ddc sur le développement et la coopération, 36p. www.ddc.admin.ch

Dekeyser PL, Villiers A. 1956. Contribution à l'étude du peuplement de la Mauritanie. Notations écologiques et biogéographiques sur la faune de l'Adrar. Mém. Inst. Franc. Afr. Noire, 44: 1222.

https://www.researchgate.net/.../Catalogu e-des-Mammiferes-

Dubois A. 1992. Notes sur la classification des Ranidae (Amphibiens anoures). Bull. Mens. Soc. Linn. Lyon, 61: 305-352. https://www.persee.fr/doc/linly_03661326_1992_num_61_10_11011

Ezemonye L, Enuneku A. 2005. Evaluation of acute toxicity of cadmium and lead to amphibian tadpoles (toad: Bufo maculatus and frog: Ptychadena bibroni). Journal of Aquatic Sciences, 20(1): 33-38 http://dx.doi.org/10.4314/jas.v20i1.2003 6

Ezemonye L, Enuneku A. 2011. Biochemical Alterations in Hoplobatrachus occipitalis Exposed to Sub Lethal Concentrations of Cadmium. Turkish Journal of Fisheries and Aquatic Sciences 11: 485-489. Doi: 10.4194/1303-2712-v11_3_21

FAO. 2016. Situation mondiale des pêches et de l'aquaculture. $227 \mathrm{p}$. www.fao.org/3/ai5555f.pdf

Frost DR. 1985. Amphibians Species of the World Lawrence, Kansas: allen Press 
and Assoc. Syst. Coll, 1987 (3): 830-833. Doi: $10.2307 / 1445694$

Frost DRT, Faivovich J, Bain RH, Haas A, Haddad CFB, De Sà RO, Channing A, Wilkinson M, Donnellan SC, Raxworthy CJ, Campbell JA, Blotto JD, Green Wheeler WC. 2006. The Amphibian tree of life. Bulletin of the American of Natural History, 297: 1-370. taxonomicon.taxonomy.nl/Reference.asp $\mathrm{x}$ ? id=5337

Grushwitz MS, Moormann S, Kromer G, Gietrich H, Boeck G, Gershwin ME, Boyd R, Wick G. 1991. Phenotypic analysis of skin infiltrates in comparaison with peripheral blood lymphocytes, spleen cell and thymocytes in early avian scleroderma. J Autoimmun 4:

577-593.

https://www.sciencedirect.com/science/a rticle/.../0738081X949029...

Guerry AD, Hunter JM. 2002. Amphibian distributions in a landcape of forest and agriculture: an examination of landcape composition and configuration. Conservation Biology, 16: 745-754. https://pdfs.semanticscholar.org/.../c54ae b6553f593c602c6d55630...

Heyer WR, Donnelly MA, Mcdiarmid RW, Hayek LAC, Froster MS. 1994. Measuring and Monitoring Biological Diversity. Standard Methods for Amphibians. Smithsonian Institution Press: Washington \& London; 364p. https://pubs.er.usgs.gov/publication/5200 175

Idowu ET, Amaeze NH, Adie PI, Otubanjo OA. 2014. Heavy metal bioaccumulation and biomarkers of oxidative stress in the wild African tiger frog, Hoplobatrachus occipitalis. African Journal of Environmental Science and Technology, 8(1): 6-15. DOI: 10.5897/AJEST2013. 1603

Inger RF, Marx H. 1961. The food of amphibians. Pp. 1-86 in Mission G.F. de Witte. Exploration du Parc National de l'Upemba, Institut des Parcs Nationaux du Congo et du Ruanda-Urundi, Fasc.
64. https://amphibiaweb.org/refs/roedel.html IUCN. 2014. (International Union for Conservation of Nature) \& Conservation International. Hoplobatrachus occipitalis. The IUCN Red List of Threatened Species. Version 2016-2. www.iucnredlist.org/

James SM, Little EE. 2003. The effects of cadmium exposure on the American toad, Bufo americanus tadpoles. Environmental Toxicology and Chemistry, 22: 377-380. https://doi.org/10.1002/etc.5620220219

Kühn ER, Gevaerts H, Jacobs G, Vandorpe G. 1987. "Reproductive cycle, thyroxine and corticosterone in females of the giant swamp frog Dicroglossus occipitalis at the Equator". General and Comparative Endocrinology, 66 : 137-144. DOI : https://doi.org/10.1016/00166480(87)90358-3

La Fondation Droit Animal (LFDA), Éthique $\&$ Sciences. 2011. Droit animal éthique \& sciences. Revue trimestrielle de la Fondation LFDA. 32p. www.fondationdroit-animal.org/documents/revue92.pdf

Lescure J. 1971. L'alimentation du crapaud Bufo regularis Reuss et de la grenouille Dicroglossus occipitalis (Günther) au Sénégal. Bulletin de l'Institut Fondamental d'Afrique Noire, 33: 446466.

Loveridge A. 1942. Revision of the Afrooriental geckos of the genus Phelsuma. Bulletin of the Museum of Comparative Zoology, 89: 439 - 482.

Loveridge A. 1955. A second collection of reptiles and amphibians taken in Tanganyika territory by C. J. P. Ionides. Esq. J. E. Arf. Nat. Hist. Soc., 22: 168198. www.biodiversitylibrary.org/.../XXII_N 0.5_97_168_1955_Love.

Mady-Goma Dirat I, Kimpoudi C, Mikia M, Tsoumou A, Vouidibio J, Pandare D. 2012. Study of an Edible Frog of Brazzaville: Hoplobatrachus occipitalis: Ranidae (Günther, 1858). I. Res. J. 
Biological Sci. $\quad$ 1(6): 10-17. https://www.yumpu.com/.../hoplobatrach us-occipitalis-ranidae-isca

Morin R. 2008. Élevage de la grenouille. Document d'information DADD-10. Ministère de l'Agriculture, des Pêcheries et de l'Alimentation. 9 p. http://www.mapaq.gouv.qc.ca/Fr/Peche.

Neveu A. 2004. La raniculture est-elle une alternative à la récolte ? Etat actuel en France. INRA. Prod. Anim. 17 : 167-175. https://www6.inra.fr/productionsanimales/2004...17/...2004/Laraniculture-est-elle-un...

Noble GK. 1924. A new Spadefoot Toad from the Oligocène of Mongolia with a summary of the evolution of the Pelobatidae. American Museum Novitates, 132: 1-15. http://hdl.handle.net/2246/3217

Nzigidahera B. 2006. Note sur Hoplobatrachus occipitalis (Günther), espèce comestible au Burundi. Institut National pour l'Environnement et la Conservation de la Nature (INECN), Burundi. Bull. Sc. INE. C. N, 1: 1-14. bi.chm-cbd.net/biodiversity/bulletin...dubulletindeja.../bulletin_1.../1/bulletin_1.pdf

Olvera-Novoa MA, Ontiveros-Escutia VM, Flores-Nava A. 2007. Optimum protein level for growth in juvenile bullfrog (Rana catesbeiana, Shaw, 1802). Aquaculture, 266(10): 191-199. www.academia.edu/.../Optimum_protein _level_for_growth_in_juv...

Omonona AO, Jubril AJ, Akinnibi OF, Adekola AA. 2016. Cadmium BioAccumulation and the Associated Biomarkers in Edible Frog Species (Hoplobatrachus occipitalis) in Ibadan, Oyo State, Nigeria. World Vet J, 6(2): 70-79.

wvj.science-

line.com/.../World\%20Vet.\%20J.\%206(2 $\% 2070-79, \ldots$

Onadeko AB, Egonmwan RI, Saliu JK. 2011. Edible amphibian species: local knowledge of their consumption in southwest Nigeria and their nutritional value. West African Journal of Applied Ecology, 19(1): 67-76. https://www.ajol.info/index.php/wajae/ar ticle/view/77567

Parker HW. 1936 Amphibians from Liberia and the Gold Coast. Zoologische Mededelingen Leiden, 19: 87-102. research.amnh.org/.../amphibia/.../Parker -1936-Zool.-Meded.-Leid...

Perret JL. 1966. Les amphibiens du Cameroun. Thèse de doctorat de Neuchâtel, 464p.

Poynton JC, Broadley DG. 1985. Amphibiens Zambesiaca 2. Ranidae. Ann. Natal Mus., 27: 115-181. 87-102. https://amphibiaweb.org/refs/roedel.html

Rödel MO, Spieller M. 2000. Trilingual keys to the Savannah-Anurans of the Comoé National Parc, Ivory Coast. Stuttgarter Beitr. Naturk. Ser. A Nr., 620: 1-31.

Rödel MO. 1995. Phrynobatrachus francisci im Comoé-Nationalpark, Elfenbeinküste: Lebensräume, Aktivität und Nahrung in der ausgehenden Trockenzeit. Salamandra 31: 79-92. www.salamandrajournal.com/index.../1995...31/...roedelm-o-1/fi...

Schiøtz A. 1999. The Treefrogs of Africa. Series: Edition Chimaira: Chimaira, Frankfurt am Main, Germany; 350 p. research.amnh.org/vz/herpetology/5_6a mphibia/?action=bib...

Scortecci G. 1936. Gli anfibi délia Tripolitania. Atti Soc. Ital. Sci. Nat., 75:

129-226. https://www.researchgate.net/.../Bibliogr aphy-of-North-African-HerpetologySmithso...

Sobha K, Poornima A, Harini P, Veeraiah K. 2007. A study on the biochemical changes in freshwater fish Catla catla exposed to the heavy metal toxicant, cadmium chloride. Kathmandu University Journal of Science, Engineering and Technology, 1: 4-11.

Spieler M, Linsenmair KE. 1998. Migration patterns and diurnal use of shelter in a ranid frog of a West African savannah: a 
telemetric study. Amphibia-Reptili, 19: 43-64. Doi: 10.1163/156853898X00322

Tohé B, N'Guessan EA, N'Goran GK. 2016. Reproduction of African Tigrine Frog Hoplobatrachus occipitalis in Banco National Park (Ivory Coast). International Journal of Science and Research (IJSR). 5(1): 2319-7064. https://www.ijsr.net/archive/v5i1/NOV1 52680.pdf

Tohé B. 2009. Reproduction et régime alimentaire de trois espèces d'anoures des habitats dégrades du Parc National du Banco (Côte d'Ivoire): Ptychadena mascareniensis, $P$. pumilio et Hoplobatrachus occipitalis. - PhD thesis, Université d'Abobo-Adjamé, Abidjan, Côte d'Ivoire, $132 \mathrm{p}$.

van den Elzen P, Kreulen DA. 1979. Notes on the vocalisations of some amphibians from the Serengeti National Park, Tanzania. Bonner zoologische Beiträge, 30: 385-403.
www.zobodat.at/.../Bonner-ZoologischeBeitraege_30_0385-0403....

Volgiatzis AK, Loumbourdis N. 1997. Uptake, tissue distribution and depuration of cadmium $(\mathrm{Cd})$ in the frog Rana ridibunda. Bulletin of Environmental Contamination and Toxicology, 59: 770-776.

Wells KD. 1977. The social behaviour of anuran amphibians. Animal Behaviour, 25: 666-693. http://dx.doi.org/10.1016/0003-3472 (77)90118-X

Whitfield SM, Bell KE, Philippi T, Sasa M, Bolaños F, Chaves G, Savage JM, Donnelly MA. 2007. Amphibian and reptiles declines over 35 years at $\mathrm{La}$ Selva, Costa Rica. PNAS, 104(20): 83528356. DOI: 10.1073 / pnas.0611256104

Zug GR. 1987. Amphibians and reptiles of the Outamba-Kilimi region, Sierra-Leone. $J$. Herpetol. Ass. Afr., 33 : 1-4. DOI: 10.1080/04416651.1987.9650167 